\title{
LAST LOVERS BY WILLIAM WHARTON IN THE OPINIONS OF SENIORS
}

\author{
MAGDA WIETESKA \\ Institute of Pedagogy, University of Wrocław, \\ ul. J. W. Dawida 1, Wrocław, Poland \\ E-mail address: mag.wieteska@gmail.com
}

\begin{abstract}
The issues of old age, once neglected in terms of reflection and research on this period of life, in recent years took on another dimension. With the growth of the elderly population in the world, more attention is gradually paid to issues related to improving the quality of life of seniors. Of particular interest are those aspects of life that have a direct impact on the sense of well-being of the elderly, namely: family, health, finances. The aspect of health is, however, considered mostly in the context of an overall psychophysical fitness, access to health care, adequate pensions enabling the purchase of medicines, rehabilitation, etc. In contrast, they less frequently deal with issues related to sexual attractiveness of the seniors and their erotic needs. Old age still does not go hand in hand with the sexual appeal. Elderly women are seen as unnecessary, invisible. They are not perceived as being able to evoke sexual desire. This social reception affects the senior women's perception of themselves. In the eyes of a community an elderly woman may still be attractive intellectually, but not physically. Stereotypes built around the old age also assume that people in late adulthood have no sexual needs.
\end{abstract}

Key words: late adulthood, old age, seniors, William Wharton, novel, femininity, University of the Third Age, stigma, stereotyping, sexuality, erotica, sex

The story of the novel by William Wharton is set in the seventies of the last century. The fifty-year-old American John arrives in Paris after parting with his wife to devote himself to his passion - painting. He takes no savings with him, living almost like a beggar, on the streets. During one of his painting sessions in the open air he meets a seventy-two-year old French woman, Mirabelle. She is an unusual elderly lady - she practices yoga, plays the harpsichord, speaks foreign languages and is also well read. After the death of her parents and older sister she lives alone, with no children, husband or friends. She is also blind, although lack of sight does not prevent her desire for self-realization. On the contrary, it enhances her cognitive needs. Mirabelle's occupation therefore defies the thesis that old age is characterized by gradual withdrawal 
from active life, giving up previously performed roles and isolation from the larger surroundings (Kałużny, 2002). It is the stereotyping of the elderly people which stigmatizes them and influences the way in which they are treated. The strength of stereotypes also affects the behavior of the seniors themselves, who surrender to the expectations of the community (Eazarewicz, 2015, p. 26). Thus a phenomenon of self-fulfilling prophecy is created. It is not only the active life of the heroine of Last Lovers that separates her from the stigmatizing view of the elderly. Her physical condition also strays from the typical image of seniors, women in particular. The view on senior women is mentioned by Dorota Niewiedział (2014, p. 263): "Today's senior is faced with an exclusion from culture, and in the best case she is associated with a stereotype in which her most important traits are unattractive appearance, the envy of youth, struggle for attention or the loss of femininity". Even in the case of appearances, Mirabelle differs from the majority of women of similar age: she is slim, graceful, agile, quick, brave and full of life. Without a doubt one can consider her an attractive woman, both in body and spirit. In spite of this, in the eyes of fifty-year-old John she for some time remains "an old lady". The American's perception shifts only as a result of the change in his relations with Mirabelle - when they establish an erotic bond. Then the descriptions of the Parisian become simply depictions of an appealing woman. A woman who has a delicate and kind face, soft, narrow lips, hair tied into a long braid and looks like a small girl, a teenager (Wharton, 1991, p. 192, 197, 213, 218). The American even concludes that "it really is hard (...) to believe (...) that she's seventy-two years old" (Wharton, 1991, p. 232).

For some readers these physical depictions seem hardly credible. The reason for that could be popular opinion on elderly women, described as "invisible". "This situation is considered oppressive by the elderly women and it negatively affects their self-esteem or acceptance of their own bodies. The more their physical image strays from the culturally propagated model, the greater their lack of approval for their body and marks of old age such as grey hair, wrinkles or less firm skin" (Niewiedział, 2014, p. 269). The heroine of Last Lovers does not feel like that, but perhaps it is due to the fact that, as a blind person, she couldn't have observed the passing of years and its effect on her body. On the other hand, it is clear that she fears seeing her own, old body, which indicates that she is aware of the changes taking place in her appearance. She says it directly to her lover John: "You must promise to hide your portraits of me and take away all the mirrors. (...) I do not think I could possibly look at myself" (Wharton, 1991, p. 357). He in turn tells her that she is a very attractive woman. The perception of women in their late adulthood as less attractive compared to younger women and less attractive compared to younger ones and their male peers is explained by the theory of evolution. Physical attractiveness and fertility are strongly correlated. "Additional studies have supported the theory of an existence of a double standard of attractiveness / appearance. This meant that a youthful appearance is more important in case of women than men, and as a consequence - elderly women will be judged more negatively" (Niewiedział, 2014, p. 268). 
Elderly women tend to perceive themselves solely on the basis of their physical appearance and not their own, often youthful, identity. "The physical signs of aging, such as gray hair or wrinkles, are treated as a disguise, or even a prison from which one cannot break free" (Niewiedział, pp. 269-270). This explains the attitude of women in old age. One of the behaviors consists of hiding (lying about) their age through numerous rejuvenating treatments. The second demeanor is characterized by seeming indifference to those spheres of life in which physical attractiveness matters.

\section{(A)SEXUAL SENIORS}

Sex of the elderly still remains a taboo subject. It is rarely brought up, as if erotic love could be attributed exclusively to younger people. The reason for this standpoint is a theoretical gradual disappearance of sensual needs in old age. It is a stereotype and a myth. The desire for sexual intercourse is normal and healthy at any age in adulthood (Hamilton, p. 157). People in late adulthood therefore have the same needs as younger people. The only difference is in the possibility of its realization. Age-related illnesses often limit and sometimes outright prevent sexual activity. Chronic diseases such as diabetes, hypertension and cardiac or urological diseases negatively affect the quality of sex life (Hamilton, p. 89). Also, medicines may cause side effects that include reduction or loss of libido.

Stereotypes concerning a reduction and even lack of erotic needs in the elderly is also explained by the effect of cohort. This is due to the fact that people who were brought up in the times with less social tolerance than today are reluctant to talk on topics related to sexuality. Researchers immediately reach the conclusion that seniors do not have a sex life, while in truth they simply do not discuss it (Hamilton, p. 158).

And those elderly people who have the courage to talk about their sex life, are stigmatized by the public. They are then met with embarrassment and indignation (Krasuski, \& Shepherd, 2015, p. 87). The community, if it has to, is more prone to accept "a randy old man" than "an inappropriately and inadequately behaving elderly lady" (Krasuski, \& Shepherd, 2015, pp. 87-88).

The seniors themselves also are reluctant to engage in an erotic activity. Changes in appearance, reduced physical fitness become the causes for fear of confrontation with a potential sexual partner. "How will she react to me?", "Can I do it?" "Will I be laughed at?" - these are the most common questions put before oneself. The fear of disgrace and rejection is sometimes so strong that it effectively prevents an establishment of intimate relationship.

On average women live longer than men. As a result there is more women than men in the same age group. This leads to a situation in which senior women, due to the lack of a partner, are less sexually active than women in the younger age group. Again - this observation can lead to the wrong conclusion, 
that if elderly people do not engage in sexual intercourse, then they have no desire to begin to do so. Yet another group is formed by the widowed persons, who due to the memory of their deceased husband/wife and certain loyalty does not come into another intimate relationship. This problem affects primarily women (Krasuski, \& Shepherd, 2015, p. 88).

For a part of the society sex is also associated with procreation, which in the case of female seniors is no longer possible. However, sexual activity is still very much available. Paradoxically, it is at the time when a woman is no longer capable to reproduce that the intercourse can be very satisfying for her. She no longer needs to use contraception and can indulge herself in sensual pleasure with almost no limitations. The only boundaries in that case are the individual needs of a senior and both his/her and the partner's physical capabilities. Even though in old age the need for stimulation is reduced and the time of reaction extends, these are completely natural processes. It is worth adding that a large part of seniors is comprised of people both physically and mentally active, who feel sexual needs and are able to fulfil them.

In "defense" of the sexuality of elderly people it is also worth mentioning the fact that sex in this age positively affects health, and "sexual longevity has a positive effect on the length and quality of life" (Lew-Starowicz, p. 121). The intensity of sexual activity doesn't change with age (Hayflick, 1994, p. 136), although the erotic needs can undergo modifications in different stages of life (Wawrzyniak, 2011).

\section{POSITIVE AGEING}

The period of old age is characterized by reminiscing to often very distant memories, possibly only due to sustained long-term memory. Also, the crystalized intelligence is proved to increase in this stage of life. It means that - contrary to the stereotypes - seniors do not have to be physically or intellectually weak, they can possess good psychophysical condition, enjoy life, have plans for the future. And although the worsening of health linked with aging limits physical strength, the abilities gained before and sustained with regular training allow them to still be viable despite the effects of inevitable perceptive-motoric changes.

Additionally, life according to the theory of positive ageing assumes the existence of certain actions. Robert D. Hill writes that they are undertaken "in order to increase the well-being, even in the case of health decline connected with ageing and the loss of someone close." (2010, p. 28). By looking at the life of Mirabelle, one can assume that she lived according to the mentioned theory. This theory assumes that a human's goal is the pursuit of happiness (welfare) through affirmation and acceptance of one's life in all its stages. This objective is constituted based on the ability to experience positive emotions, engaging in activities and giving sense to one's life. It is achieved through kind 
relationships with others, physical and mental autonomy as well as personal development (Wawrzyniak, 2015, p. 118). "The mission of positive ageing is very clear - to add more life to your years, and not only more years to your life" (Vaillant, 2007, p. 335).

It revolves around the assessment of a sense of well-being both in subjective and objective sphere. Something which is only an inconvenience for one person can be severe hardship for another. Mirabelle from Wharton's novels accepted her blindness with relative calm, not resigning from active life due to her incapacity. Someone else in her place could have succumbed to grief, stagnation, isolation from the world and other people. This often happens even in the case of younger people who e.g. due to an accident suddenly become handicapped. And regardless of medical predictions they can take the form of a double-sided attitude: to surrender and withdraw from all activities available to them or continue the previous ones and possibly add new ones.

This intrinsic activity of seniors is precisely what improves the quality of their life in old age. One of the factors that affect the lives according to the concept of positive ageing is the maintenance of kind relationships with other people. The heroine of Last-lovers had neither family nor friends.

But loneliness caused by a lack of family was compensated by her ease of establishing relations with people and friendship with birds. The pigeons that she took care of every day with a great deal of attention additionally evoked her need of being active. As claimed by C. B. Germain and A. Gitterman, "taking care of a domestic animal or a plant can preserve the ability of maintaining relations with other people, as well as a sense of meaning and effectiveness. For example, a bird or a plant which requires care and react to attention and interest, can give joy and a feeling of affinity to an elderly person" (2008, p. 192).

\section{ELDERLY WOMAN IN THE VIEW OF SENIORS}

In order to learn the opinion of seniors on the topic of reception of Last Lovers I have conducted research on a group of persons aged 68-75. The research subjects were students of the University of the Third Age on the University of Wrocław: three women and two men. Each of them has read the novel by W. Wharton. I have used qualitative strategy. The research problems in the uncategorized casual interview were concerning especially: $1 /$ evaluation of the physical condition of the heroine, 2/ Thoughts on the romance of the heroes.

The reason for choosing this exact group for the research was the subjects' educationally-cultural activity. The students of UTA in UWr take part in various classes for cultural and educational activation. They make use of i.a. the offer of a discursive club, reading club, journalism workshops. They read books, articles, participate in discussions on the topic of literature and journalistic writing. What drew my interest in particular was how the people who are 
seniors themselves receive a novel whose main heroine is a 72-year-old who has an affair with a man 20 years younger than her. The opinions of the subjects differ. The women perceive the heroine in a different way than the men. "I have a 73-year-old wife. I know what a woman's body looks like at this age. Wharton had to devise a lot in here" (L., 75-year-old). The 68-year-old K. provides a similar insight, claiming that even seniors who take care of themselves couldn't arouse a man 20 years younger. $\mathrm{H}$. (70-year-old) pertained to her own experience: "I had a divorce ten years ago. I met with various men, so I know what it looks like in practice. Mature men are not interested in women older than them, bah, men are even not interested in women of their own age. They only look for younger women".

Mirabelle's physical condition does not have to be only an imagination of the writer, though, since the speed of aging is affected by cognitive processes, such as regular physical and muscle exercises, which hamper or slow the decline of intellectual capabilities with age (Hill, 2010, p. 28). The subjects, however, undermine this thesis. "I don't know any woman at this age whom I could describe in a way Wharton did - that she is slim, pretty and attractive, well, in the sexual sense. Maybe except for famous actresses, but in this case the scalpel has done its job" - another woman claims (I., 69-year-old). The 70-year-old W. supports this opinion; "It's hard for me to imagine having sex with a 72-year-old at the age of 50 . The thought alone seems distasteful to me". According to the seniors a woman of Mirabelle's age can be well-read, have an ear for music, be physically efficient, impress with a knowledge of foreign languages and ability to play an instrument. "But she will never be the same as a woman younger than her. She is not that age anymore, and no amount of gymnastics can change that" (H., 70-year-old), "let's not fool ourselves that after 70 one can be beautiful, slim and young" (K., 68-ear-old).

\section{INTIMACY OF THE HEROES IN THE EYES OF SENIORS}

The erotic relations of a 72-year-old woman and a man 20 years younger is in the opinion of the senior readers another fact hard to accept, a process which is hard to believe. "Weird behavior", "science-fiction", "unlikely relationship", "distasteful scenario" - such judgments were the most common when I asked about the reception heroes' romance in the novel. Only I. (69 years old) stated that such a relationship could happen in real life. The subject admitted however, that as a senior she viewed this novel entirely differently than as a young wife: "As a young married woman I rejected this kind of love, it seemed impossible, unattractive. But now I hold a different opinion, I believe that it could happen. Although the descriptions of exploring a man's body by Mirabelle were not to my liking. Because of those erotic depictions it was really hard to see love in there. I found it probably because I wanted to". 
W. (70 years old), on the other hand, claims that as a man he wouldn't be able to fall in love and have intercourse with a woman who is 20 years older than him. "It's just the way we are, corporeality is important to us. We see with our eyes and what we see arouses us. I don't believe that and old and grey-haired woman could arouse a man who is still quite young". L. (75 years) has a similar opinion, since he believes that the motive behind the romance was John's desire to live in Mirabelle's house. Meanwhile, k. (68 years old) opposes such materialistic reasoning. She said that "although a way to a man's heart leads through his stomach, it doesn't explain why John was so committed to the relationship. He did not have to live off Mirabelle as he could have returned to America at any time".

The relationships in which one of the partners is much older than the other still evokes disapproval of the society. The older the female partner is, the bigger the disapproval. The community also suspects other reasons than love for the creation and maintenance of this kind of a relationship (Lew-Starowicz, 2004 , p. 116). For such couples it is harder to live together due to the reactions of other people, and most of all the lack of social acceptance. "We imagine such partners in an intimate situation and an aesthetic discomfort occurs (Lew-Starowicz, 2004, p. 120). In the opinion of $\mathrm{H}$. (70 years old) the erotic fragments in the novel are unnecessary. She explains this stance by saying that "everyone knows what a sexual contact between a woman and a man looks like. In truth, the author could have spared himself those moments". Meanwhile, K. (68 years old) thinks that the "moments" were not supposed to evoke a feeling of arousal or disgust in the reader, but only portray erotica from the point of view of a blind virgin - Mirabelle.

It can be assumed that the readers of the novel are under the influence of a stereotype, in which sex is not appropriate in old age and "there exists a certain taboo in our society which forbids us to talk about sex among seniors" (Bonowicz, 2015).

\section{CONCLUSIONS FROM THE RESEARCH}

In the views of senior subjects claims focusing on a lack of credibility of events in the novel clearly prevail. Some of them think that a 72-year-old woman cannot be physically appealing to a 50-year-old man. They also believe that such love is impossible in real life. Only one senior admitted that she believes in an establishment of this kind of relationship outside literature.

The descriptions of erotic moments are in the opinion of the subjects an unnecessary element, perceived as distasteful or even disgusting. This view correlates with opinions of some Internet users: "I think that the author went too far, while reading I was nauseous not simply because of inappropriateness - the lovers being in a senile age, but due to the excess of sweetness and care which this unusual pair exhibits on a daily basis" (Tet, 2015), "Are «Last 
Lovers» a geriatric version of Romeo and Juliet? Well, this thought has crossed my mind... Has Wharton created an alibi for people who have significantly younger partners, as if it wasn't only about money and the position of the older partner?" (Tunio, 2015), "In books I appreciate their credibility. In fantasy I can value the honesty of feelings, in science-fiction, the possibility that something like that can truly happen. But in this kind of love I will never believe" (Mallwa, 2015).

In summary, intercourse for old people still evokes in the society a feeling of inappropriateness, distaste, embarrassment. These opinions are even more determined when an intimate relationship occurs between an older woman and a younger man. According to the society the roles performed by the elderly should revolve around the categories of family (mother, grandmother, great-grandmother), formal (a member of an association, religious organization), informal (neighbor, member of a social group), professional (retired person, pensioner) and social (citizen of a country and the world). There is no place for a senior-lover in this categorization. This possibility is not even taken into consideration.

The causes of such evaluation can be found in the culture of youth. Maria Straś-Romanowska speaks outright of the negative consequences of the cult of youth, which contributes to marginalizing the problems of old age, ageism and promoting strength, fitness and attractiveness of the body (2010, p. 13). And the old body still raises resistance from giving it a function connected with attributes of the youth and in it - the sexual role. Especially the sexual one.

\section{REFERENCES}

[1] Bonowicz, K. (2015). Seks nie przechodzi na emeryture [Sex doesn't retire]. Retrieved from http://m.pomorska.pl/publicystyka/art/7269526,seks-nie-przechodzi-na-emeryture,id,t. html.

[2] Chabior, A. (2015). Jakość życia a przestrzeń fizyczna seniorów [Quality of life and physical space of seniors]. In: A. Fabiśs, J. K. Wawrzyniak, \& A. Chabior (Eds.). Ludzka starość. Wybrane zagadnienia gerontologii społecznej [A human's old age. Selected issues of social gerontology]. Kraków: Impuls.

[3] Germain, C. B., \& Gitterman, A. (2008). The Life Model of Social Work Practice. Columbia: University Press.

[4] Hayflick, L. (1994). Jak i dlaczego się starzejemy [How and why do we age]. Warszawa: Książka i Wiedza.

[5] Hill, R. D. (2010). Pozytywne starzenie się. Młodzi duchem w jesieni życia [Positive ageing. The young at heart at the autumn of life]. Warszawa: Gandalf.

[6] Kałużny, R. (2012). Idea kształcenia ustawicznego a aktywność edukacyjna seniorów [The idea of lifelong learning and educational activity of the seniors]. Biblioteka gerontologii spotecznej. Edukacyjna przestrzeń starości. Wybrane konteksty refleksji i badań [Library of social gerontology. Educational sphere of old age. Selected contexts of reflections and research], 1, 30-42

[7] Krasuski, T., \& Owczarek, K. (2015). Źródła problemów seksualnych osób starszych [Sources of sexual problems of elderly people]. In: K. Owczarek, \& M. A. Łazarewicz (Eds.). Pogoda na starość. Podręcznik skutecznego wspierana seniorów [A forecast for old age. A guide to successfully encourage seniors]. Warszawa: Wolters Kluwer. 
[8] Lew-Starowicz, Z., \& Fijałkowska-Grabowiecka, A. (2004). Seks kontrowersyjny [Controversial sex]. Warszawa: Dom Wydawniczy Bellona.

[9] Łazarewicz, M. A. (2015). Wstęp - zrozumieć starość [Introduction - to understand old age]. In: K. Owczarek, \& M. A. Łazarewicz (Eds.). Pogoda na starość. Podręcznik skutecznego wspierana seniorów [A forecast for old age. A guide to successfully encourage seniors]. Warszawa: Wolters Kluwer.

[10] Mallwa. (2015). Ta ksiażka budzi, chyba nie tylko we mnie mieszane uczucia..., [This book evokes, probably not only in me, mixed feelings...]. Retrieved from http://lubimyczytac.pl/ ksiazka/127553/spoznieni-kochankowie/wszyscy.

[11] Niewiedział, D. (2014). Już nie kobieta? Samoocena atrakcyjności ciała starzejących się wdów [No longer a woman? Self-evaluation of the attractiveness of body of ageing widows]. Dyskursy młodych andragogów [Discourses of young andragogists], 15, 263-270.

[12] Straś-Romanowska, M. (2010). Możliwości i ograniczenia rozwoju człowieka starszego związane z przemianami cywilizacyjnymi. Uniwersytety Trzeciego Wieku wobec problemów starzejącego się społeczeństwa [Opportunities and limitations of development of an elderly person connected with civilizational changes. Universities of the Third Age regarding problems of an ageing society.] In: A. Kobylarek, \& E. Kozak (Eds.). Starość u progu XXI wieku [Old age on the verge of $21^{\text {st }}$ century]. Wrocław: Uniwersytet Wrocławski.

[13] Tet. (2015). Przeczytana z braku laku...[A book read from lack of any other]. Retrieved from http://lubimyczytac.pl/ksiazka/127553/spoznieni-kochankowie/wszyscy.

[14] Stuart-Hamilton, I. (2000). Psychologia starzenia się. Wprowadzenie. [Psychology of ageing. Introduction]. Poznań: Zysk i S-ka.

[15] Tunio. (2015). Czy Spóźnieni kochankowie to geriatryczna wersja Romea i Julii? [Are Last Lovers a geriatric version of Romeo and Juliet?]. Retrieved from http://lubimyczytac.pl/ ksiazka/127553/spoznieni-kochankowie/wszyscy.

[16] Vaillant, G. E. (2004). Pozytywne starzenie się [Positive ageing]. In: P. A. Linley, \& S. Joseph (Eds.). Positive Psychology in Practise. New Jersey: John Wiley \& Sons, Inc.

[17] Wawrzyniak, J. K. (2015). Jakość życia i satysfakcja życiowa w starości [Quality of life and life satisfaction at old age]. In: A. Fabiś, J. K. Wawrzyniak, \& A. Chabior (Eds.). Ludzka starość. Wybrane zagadnienia gerontologii spotecznej [A human's old age. Selected issues of social gerontology]. Kraków: Impuls.

[18] Wharton, W. (1991). Last Lovers. London: Granta Books. 